\title{
Supporting Information: Single-Event Kinetic
}

\section{Model for 1-Pentene Cracking on ZSM-5}

Tassilo von Aretin ${ }^{a, b}$, Stefan Schallmoser ${ }^{a, b}$, Sebastian Standl ${ }^{a, b}$, Markus Tonigold ${ }^{c}$,

Johannes A. Lercher ${ }^{a, b}$ and Olaf Hinrichsen ${ }^{a, b *}$

${ }^{\text {a}}$ Technische Universität München, Department of Chemistry, Lichtenbergstraße 4, D-85748

Garching b. München, Germany

${ }^{\mathrm{b}}$ Technische Universität München, Catalysis Research Center, Ernst-Otto-Fischer-Straße 1, D-85748 Garching b. München, Germany

${ }^{\mathrm{c} C l a r i a n t}$ Produkte (Deutschland) GmbH, Waldheimer Str. 13, D-83052 Bruckmühl, Germany

\section{Corresponding Author}

olaf.hinrichsen@ch.tum.de 
Table S1: Calculated equilibrium mole fractions of pentene isomers at 633 and $733 \mathrm{~K}$ with Gibbs energies taken from Alberty and Gehrig. ${ }^{34}$

\begin{tabular}{l|l|l} 
Equilibrium mole fraction [-] & $\mathbf{6 3 3} \mathbf{~ K}$ & $\mathbf{7 3 3} \mathbf{~ K}$ \\
\hline Pent-1-ene & 0.025 & 0.038 \\
\hline cis-Pent-2-ene & 0.084 & 0.105 \\
\hline trans-Pent-2-ene & 0.096 & 0.112 \\
\hline 2-Methylbut-1-ene & 0.217 & 0.231 \\
\hline 2-Methylbut-2-ene & 0.546 & 0.470 \\
\hline 3-Methylbut-1-ene & 0.032 & 0.044
\end{tabular}

Table S2: Calculated equilibrium mole fractions of butene isomers at 633 and $733 \mathrm{~K}$ with Gibbs energies taken from Alberty and Gehrig. ${ }^{34}$

\begin{tabular}{l|l|l} 
Equilibrium mole fraction [-] & $\mathbf{6 3 3} \mathbf{~ K}$ & $\mathbf{7 3 3} \mathbf{~ K}$ \\
\hline But-1-ene & 0.087 & 0.119 \\
\hline cis-But-2-ene & 0.149 & 0.161 \\
\hline trans-But-2-ene & 0.237 & 0.244 \\
\hline Isobutene & 0.527 & 0.476
\end{tabular}




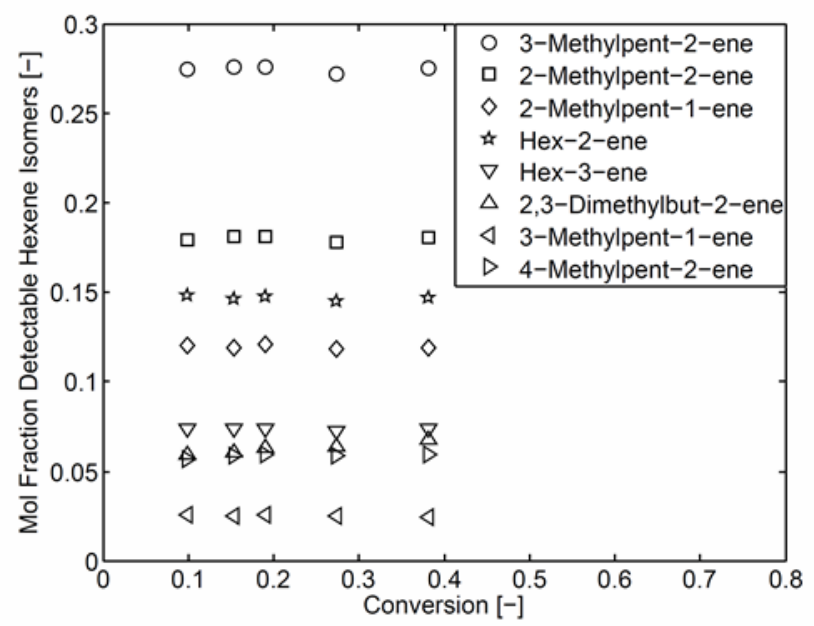

Figure S1: Mole fractions of detectable hexene isomers depending on conversion for a reaction temperature of $693 \mathrm{~K}$.

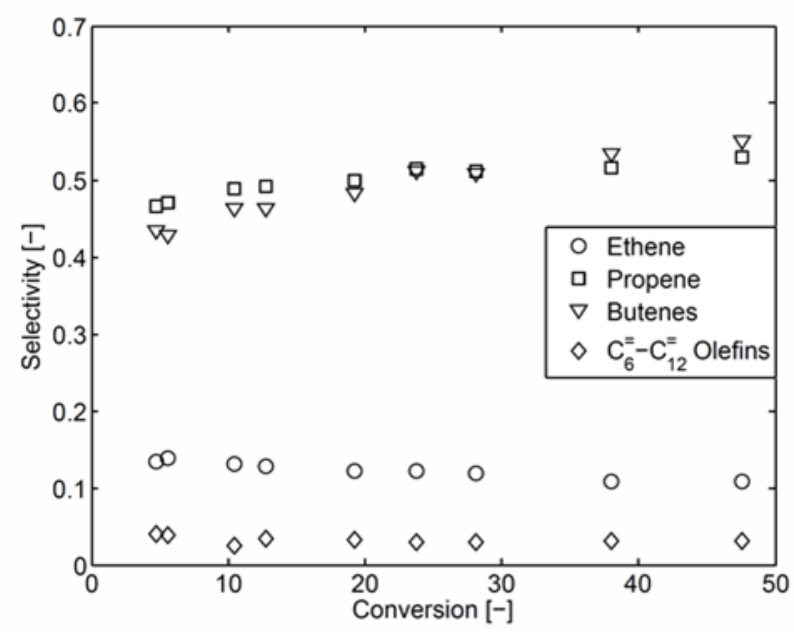

Figure S2: Product selectivities depending on conversion for a reaction temperature of $693 \mathrm{~K}$ at $42.7 \mathrm{mbar}$ partial pressure of 1-pentene and a flow rate of $400 \mathrm{Nml} / \mathrm{min}$. 


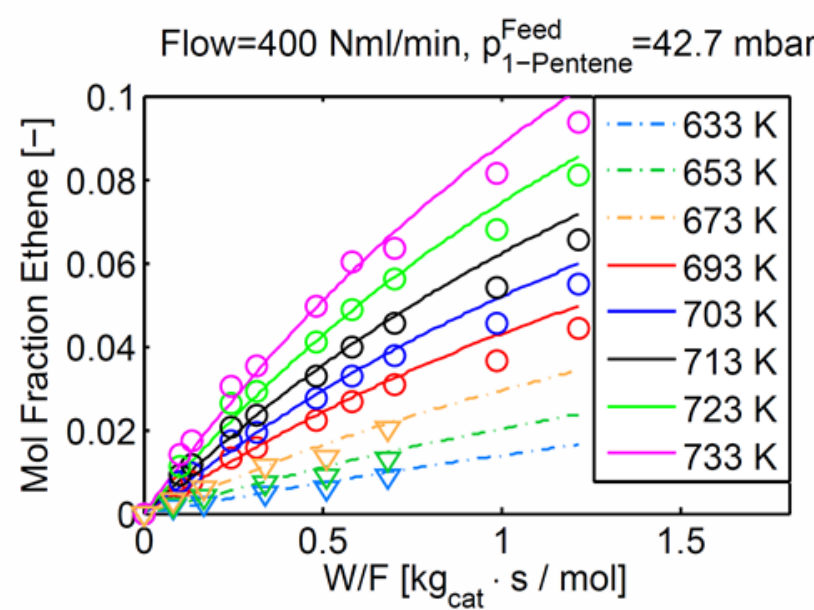

Flow $=300 \mathrm{Nml} / \mathrm{min}, \mathrm{p}_{1-\text { Pentene }}^{\text {Feed }}=42.7 \mathrm{mbar}$

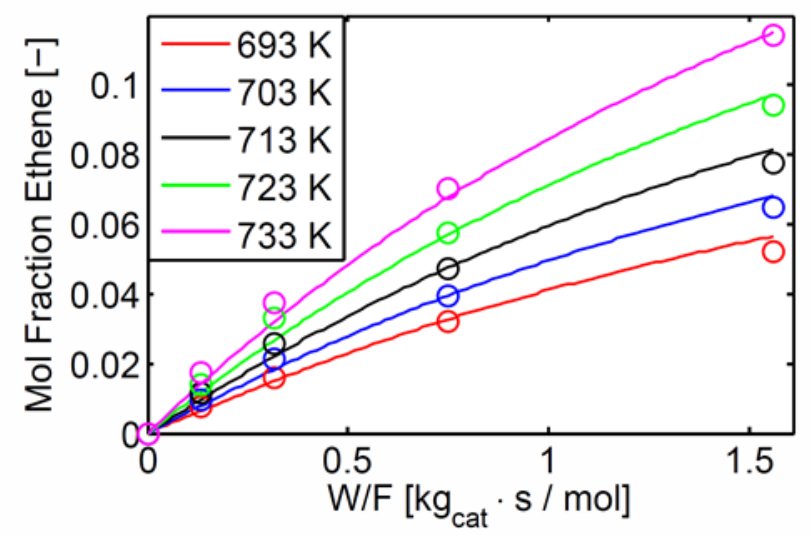

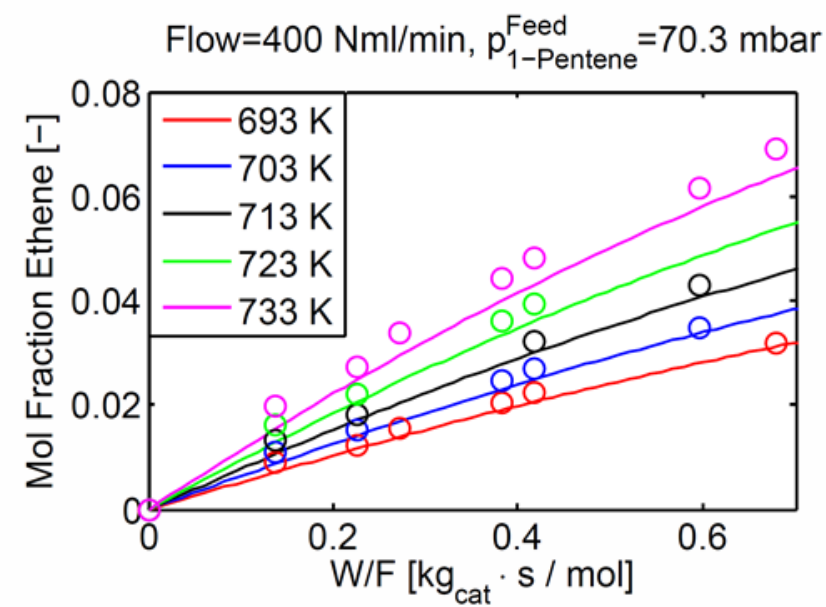

Flow $=300 \mathrm{Nml} / \mathrm{min}, \mathrm{p}_{1-\text { Pentene }}^{\text {Feed }}=70.3 \mathrm{mbar}$

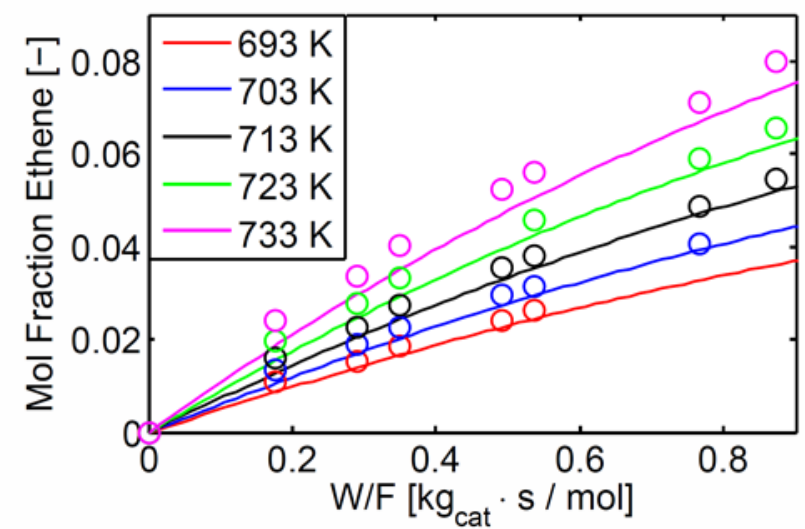

Figure S3: Mole fraction of ethene plotted over the modified residence time for experiment (data points) and kinetic model (lines) at different temperatures, two partial pressures of 1-pentene in the feed of 42.7 and 70.3 mbar as well as two flow rates at the reactor inlet of 300 and $400 \mathrm{Nml} / \mathrm{min}$. 

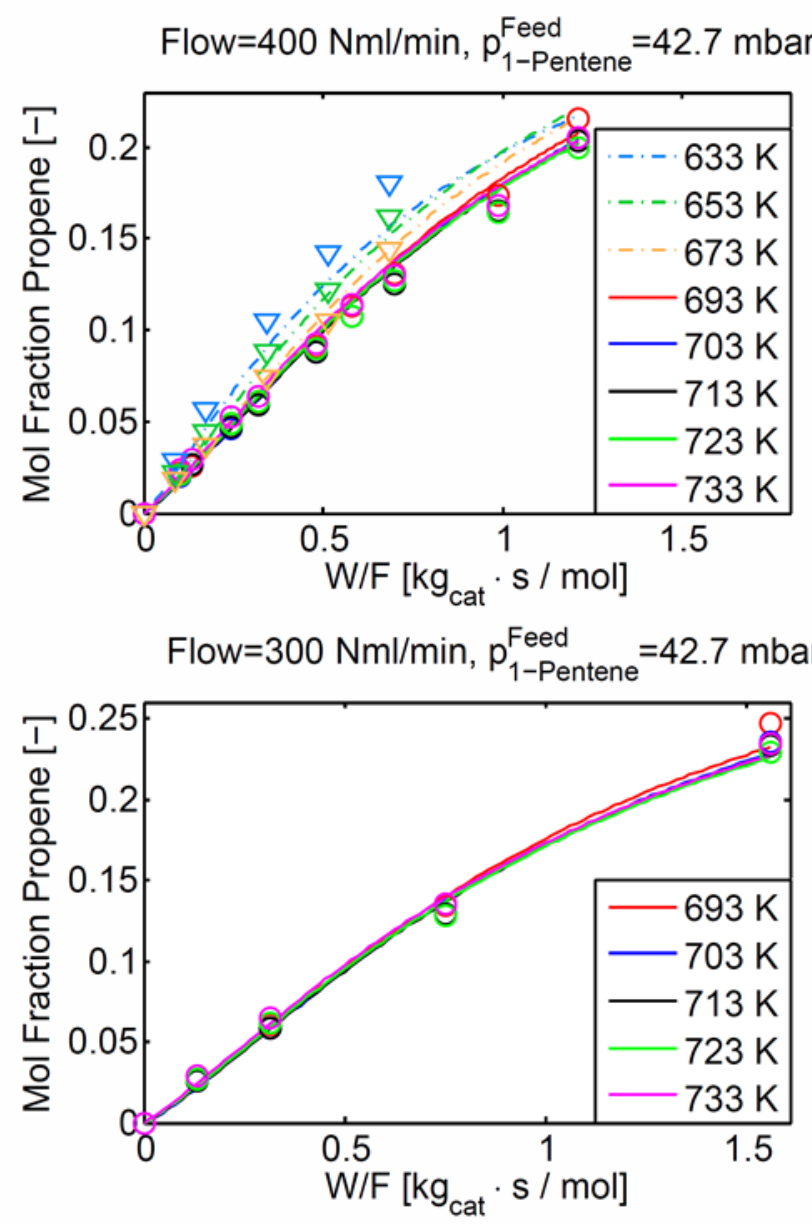

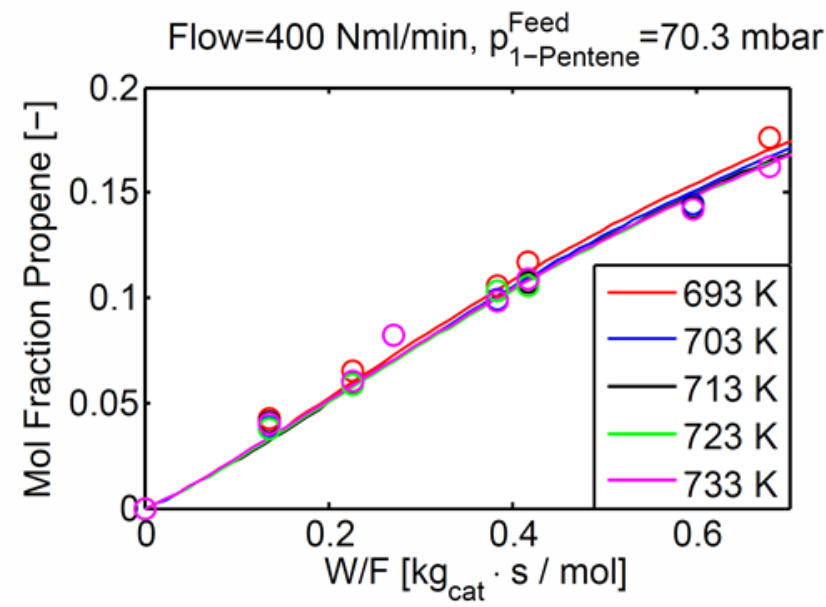

Flow=300 Nml/min, $\mathrm{p}_{1-\text { Pentene }}^{\text {Feed }}=70.3 \mathrm{mbar}$

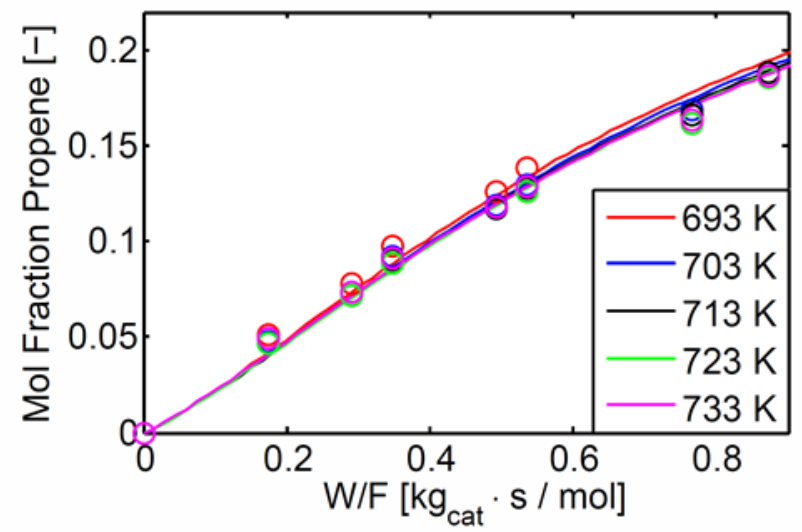

Figure S4: Mole fraction of propene plotted over the modified residence time for experiment (data points) and kinetic model (lines) at different temperatures, two partial pressures of 1-pentene in the feed of 42.7 and 70.3 mbar as well as two flow rates at the reactor inlet of 300 and $400 \mathrm{Nml} / \mathrm{min}$. 

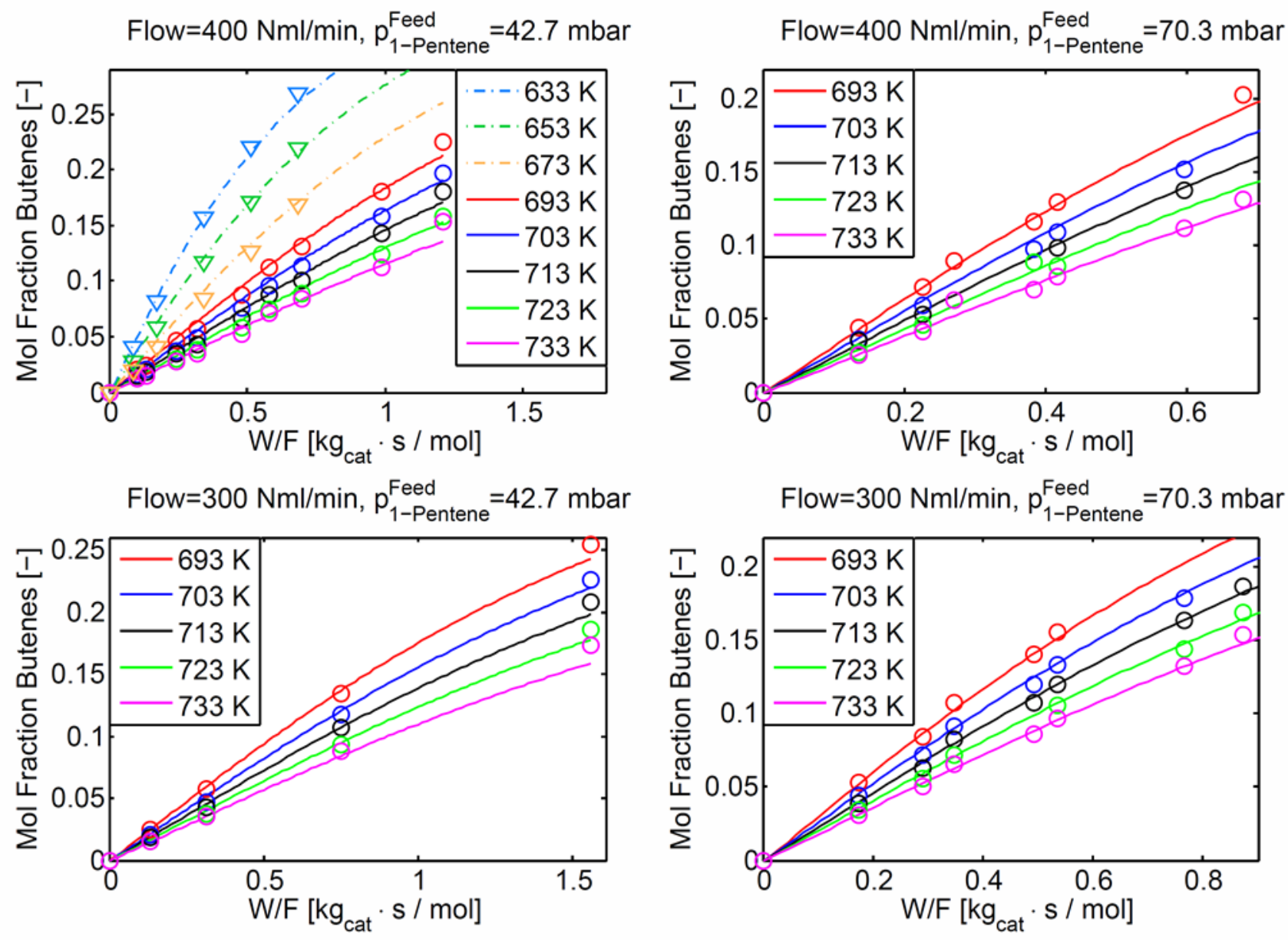

Figure S5: Mole fraction of butenes plotted over the modified residence time for experiment (data points) and kinetic model (lines) at different temperatures, two partial pressures of 1-pentene in the feed of 42.7 and 70.3 mbar as well as two flow rates at the reactor inlet of 300 and $400 \mathrm{Nml} / \mathrm{min}$. 

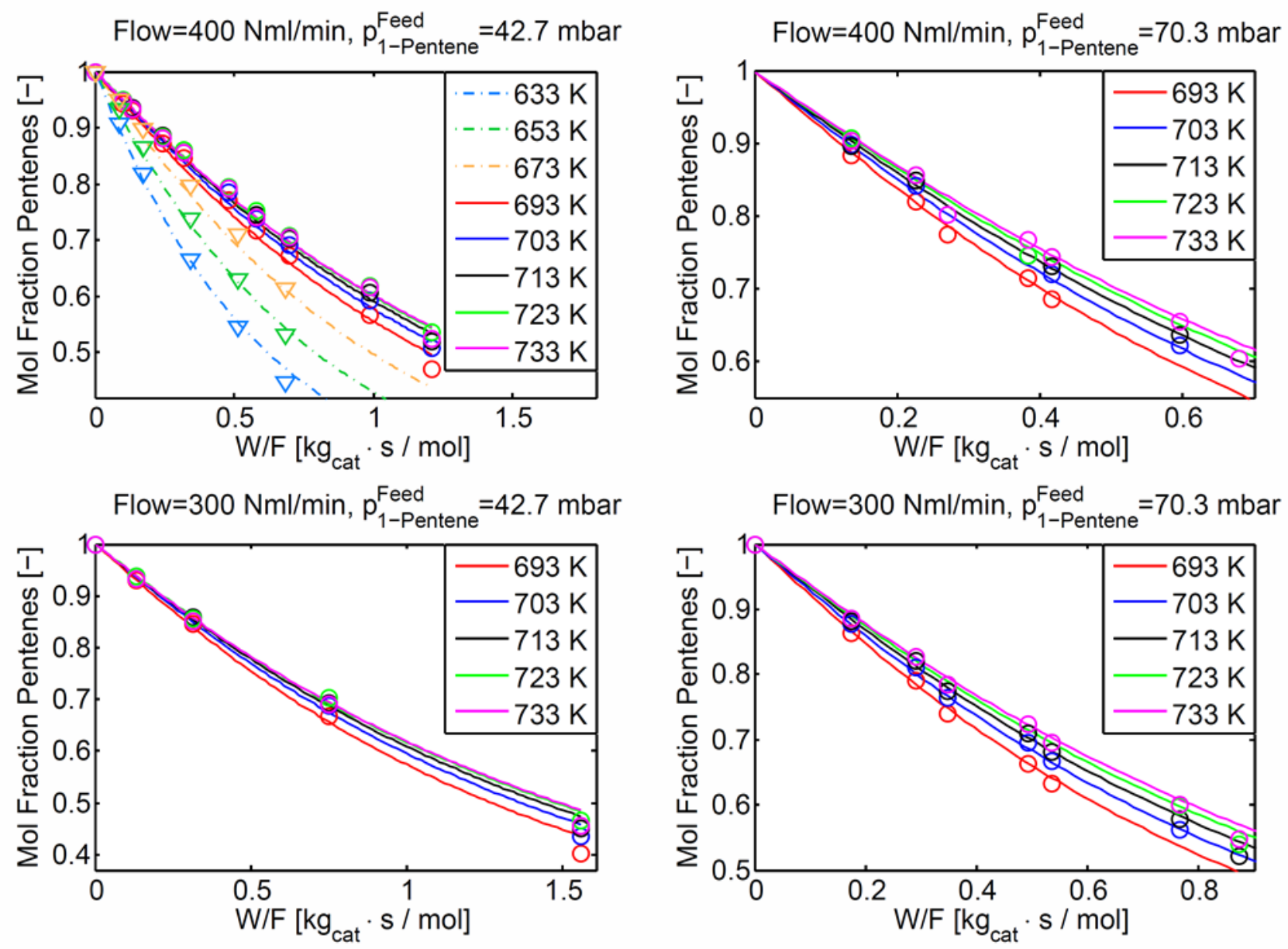

Figure S6: Mole fraction of pentenes plotted over the modified residence time for experiment (data points) and kinetic model (lines) at different temperatures, two partial pressures of 1-pentene in the feed of 42.7 and 70.3 mbar as well as two flow rates at the reactor inlet of 300 and $400 \mathrm{Nml} / \mathrm{min}$. 

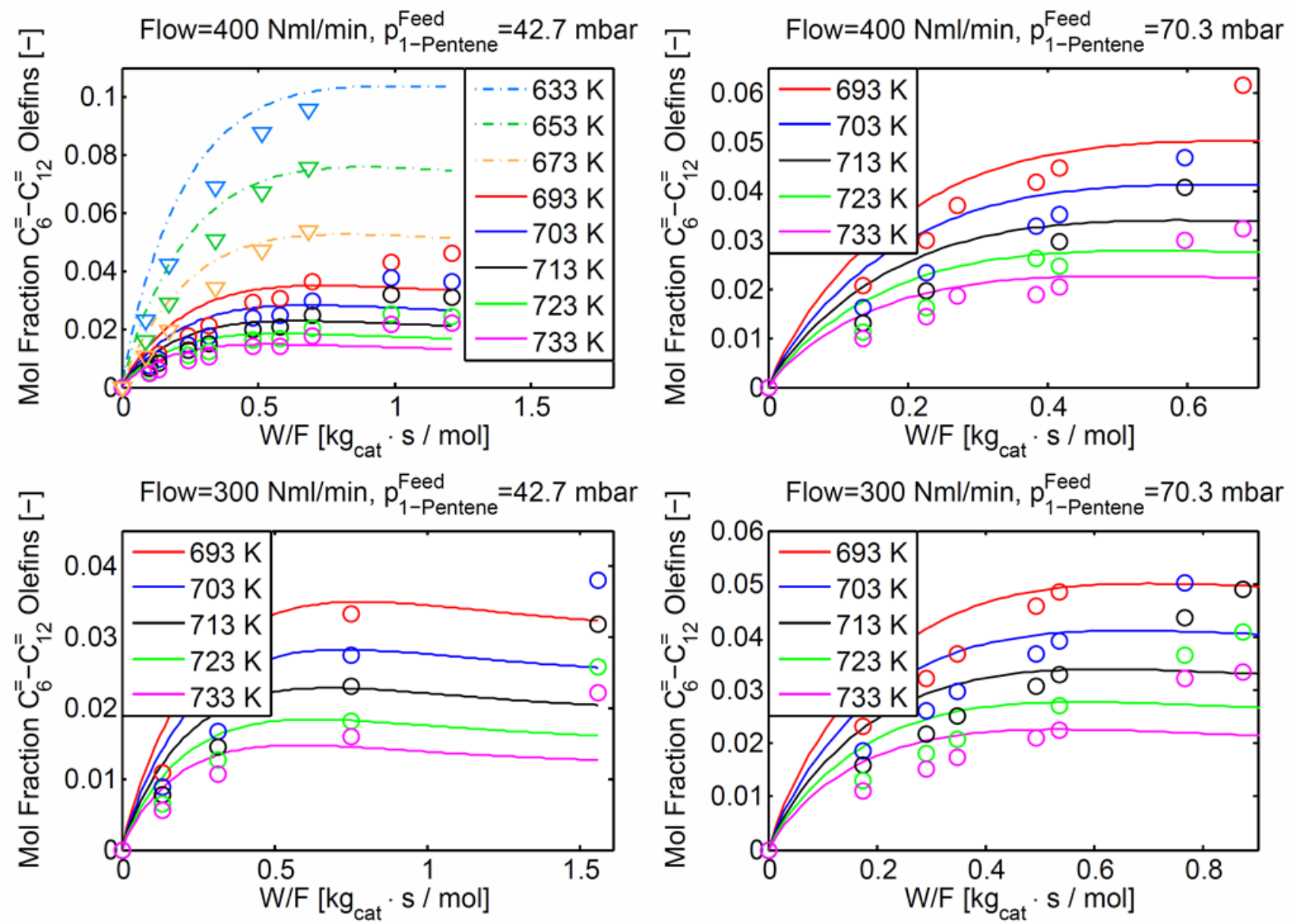

Figure S7: Mole fraction of $\mathrm{C}_{6}{ }^{-}-\mathrm{C}_{12}{ }^{2}$ olefins plotted over the modified residence time for experiment (data points) and kinetic model (lines) at different temperatures, two partial pressures of 1-pentene in the feed of 42.7 and 70.3 mbar as well as two flow rates at the reactor inlet of 300 and $400 \mathrm{Nml} / \mathrm{min}$. 
Table S3: List of different reaction networks tested with the results shown in Table 2 as well as Figure 8 obtained from reaction network RN1. RN2 to RN8 are alternative reaction networks to test the assumptions made in RN1. Column Me-sideg. states the maximum number of methyl side groups in the reaction networks, column quat. $C$. whether or not quaternary carbon atoms may be present in the considered hydrocarbons, column $(s ; p)$ whether cracking via secondary to primary carbenium ions is considered for all olefins or only for linear pentenes and column $(t ; p)$ whether or not cracking reactions via tertiary to primary carbenium ions are included. Column $C N$ max. gives the maximum carbon number of molecules considered in the reaction. The number of reaction pathways via cracking and dimerization reactions is given in columns $n C R$ and $n D I M$, respectively, and the number of olefins in the reaction networks in column nOlef.

\begin{tabular}{l|l|l|l|l|l|l|l|l} 
& Me-sideg. & quat. $C$. & $(s ; p)$ & $(t ; p)$ & $C N$ max. & $n C R$ & $n D I M$ & $n$ Olef \\
\hline RN1 & 2 & no & all & yes & 12 & 1292 & 293 & 591 \\
\hline RN2 & 2 & no & all & no & 12 & 981 & 293 & 591 \\
\hline RN3 & 2 & no & only $\mathrm{C}_{5}=$ & no & 12 & 295 & 293 & 591 \\
\hline RN4 & 3 & no & all & yes & 12 & 1930 & 599 & 916 \\
\hline RN5 & 6 & yes & all & yes & 12 & 3564 & 1441 & 1891 \\
\hline RN6 & 5 & yes & all & yes & 10 & 732 & 283 & 450 \\
\hline RN7 & 2 & no & all & yes & 10 & 439 & 115 & 244 \\
\hline RN8 & 2 & no & all & yes & 14 & 3022 & 595 & 1228
\end{tabular}


Table S4: Estimated activation energies and preexponential factors with $95 \%$ confidence intervals as well as the sum of squares of residuals (SSR) for the different reaction networks described in Table S3.

\begin{tabular}{|c|c|c|c|c|c|c|c|c|}
\hline & RN1 & RN2 & RN3 & RN4 & RN5 & RN6 & RN7 & RN8 \\
\hline $\begin{array}{l}E_{a}^{C R}(s ; p) \\
{[\mathrm{kJ} / \mathrm{mol}]}\end{array}$ & $\begin{array}{l}229.6 \\
\pm 0.9\end{array}$ & $\begin{array}{l}228.4 \\
\pm 1.0\end{array}$ & $\begin{array}{l}228.3 \\
\pm 1.0\end{array}$ & $\begin{array}{l}230.3 \\
\pm 1.0\end{array}$ & $\begin{array}{l}228.6 \\
\pm 3.3\end{array}$ & $\begin{array}{l}228.3 \\
\pm 4.5\end{array}$ & $\begin{array}{l}228.8 \\
\pm 1.0\end{array}$ & $\begin{array}{l}229.8 \\
\pm 0.9\end{array}$ \\
\hline $\begin{array}{l}E_{a}^{C R}(s ; s) \\
{[\mathrm{kJ} / \mathrm{mol}]}\end{array}$ & $\begin{array}{l}199.7 \\
\pm 0.8\end{array}$ & $\begin{array}{l}199.4 \\
\pm 0.9\end{array}$ & $\begin{array}{l}199.3 \\
\pm 0.9\end{array}$ & $\begin{array}{l}201.5 \\
\pm 1.0\end{array}$ & $\begin{array}{l}197.5 \\
\pm 2.9\end{array}$ & $\begin{array}{l}196.0 \\
\pm 4.0\end{array}$ & $\begin{array}{l}198.1 \\
\pm 0.9\end{array}$ & $\begin{array}{l}199.9 \\
\pm 0.9\end{array}$ \\
\hline $\begin{array}{l}E_{a}^{C R}(s ; t) \\
{[\mathrm{kJ} / \mathrm{mol}]}\end{array}$ & n.a. & n.a. & n.a. & n.a. & $\begin{array}{l}190.2 \\
\pm 2.6\end{array}$ & $\begin{array}{l}192.8 \\
\pm 53.4\end{array}$ & n.a. & n.a. \\
\hline $\begin{array}{l}E_{a}^{C R}(t ; p) \\
{[\mathrm{kJ} / \mathrm{mol}]}\end{array}$ & $\begin{array}{l}211.8 \\
+1.4\end{array}$ & n.a. & n.a. & $\begin{array}{l}208.8 \\
+1.1\end{array}$ & $\begin{array}{l}208.8 \\
+1.1\end{array}$ & $\begin{array}{l}204.3 \\
+4.5\end{array}$ & $\begin{array}{l}208.5 \\
+1.2\end{array}$ & $\begin{array}{l}211.9 \\
+1.3\end{array}$ \\
\hline $\begin{array}{l}E_{a}^{C R}(t ; s) \\
{[\mathrm{kJ} / \mathrm{mol}]}\end{array}$ & $\begin{array}{l}171.2 \\
\pm 0.8\end{array}$ & $\begin{array}{l}170.3 \\
\pm 0.9\end{array}$ & $\begin{array}{l}170.3 \\
\pm 0.9\end{array}$ & $\begin{array}{l}174.3 \\
\pm 0.9\end{array}$ & $\begin{array}{l}170.2 \\
\pm 1.9\end{array}$ & $\begin{array}{l}169.2 \\
\pm 2.9\end{array}$ & $\begin{array}{l}170.1 \\
\pm 0.9\end{array}$ & $\begin{array}{l}171.4 \\
\pm 0.8\end{array}$ \\
\hline $\begin{array}{l}E_{a}^{C R}(t ; t) \\
{[\mathrm{kJ} / \mathrm{mol}]}\end{array}$ & n.a. & n.a. & n.a. & n.a. & $\begin{array}{l}334.5 \\
\pm 1 \cdot 10^{4}\end{array}$ & $\begin{array}{l}226.7 \\
\pm 2067.7\end{array}$ & n.a. & n.a. \\
\hline $\begin{array}{c}A^{C R} \\
{[1 / \mathrm{s}]}\end{array}$ & $\begin{array}{l}2.18 \cdot 10^{16} \\
\pm 3.0 \cdot 10^{15}\end{array}$ & $\begin{array}{l}1.89 \cdot 10^{16} \\
\pm 2.8 \cdot 10^{15}\end{array}$ & $\begin{array}{l}1.87 \cdot 10^{16} \\
\pm 2.8 \cdot 10^{15}\end{array}$ & $\begin{array}{l}2.22 \cdot 10^{16} \\
\pm 3.5 \cdot 10^{15}\end{array}$ & $\begin{array}{l}1.75 \cdot 10^{16} \\
\pm 9.6 \cdot 10^{15}\end{array}$ & $\begin{array}{l}1.55 \cdot 10^{16} \\
\pm 1.2 \cdot 10^{16}\end{array}$ & $\begin{array}{l}1.83 \cdot 10^{16} \\
\pm 2.8 \cdot 10^{15}\end{array}$ & $\begin{array}{l}2.25 \cdot 10^{16} \\
\pm 3.2 \cdot 10^{15}\end{array}$ \\
\hline SSR & 0.0339 & 0.0382 & 0.0396 & 0.0400 & 0.0406 & 0.0490 & 0.0386 & 0.0335 \\
\hline
\end{tabular}




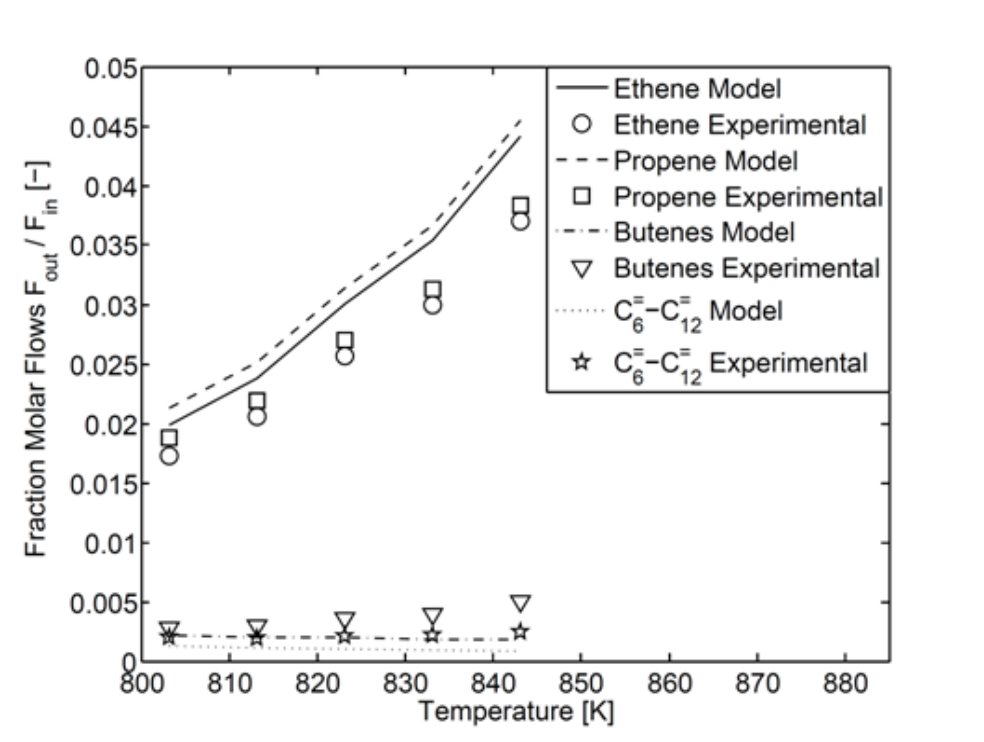

Figure S8: Extrapolation of the kinetic model with additional data points at lower conversions and higher temperatures compared to Figure 9. 

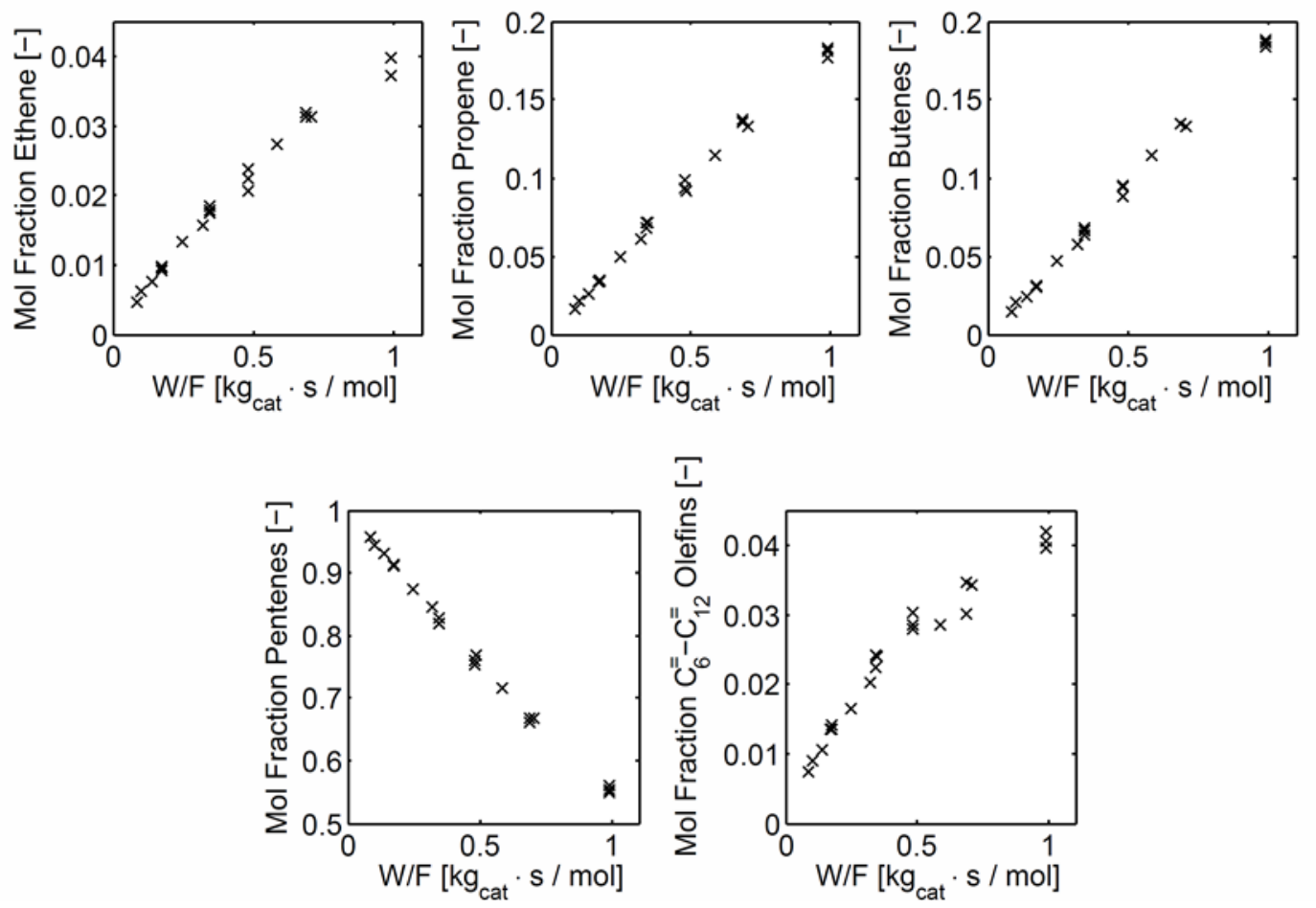

Figure S9: Reproduction measurements at one selected experimental condition of $693 \mathrm{~K}$, 42.7 mbar 1-pentene partial pressure in the feed and $400 \mathrm{Nml} / \mathrm{min}$ flow rate at the reactor inlet. 